\title{
Immune cell profile of dental pulp tissue treated with zoledronic acid
}

\author{
P. G. de Barros Silva ${ }^{1}$ (D, M. E. Q. L. Verde ${ }^{1}$, L. A. C. Brizeno ${ }^{2}$, D. V. T. Wong ${ }^{3}$,
} R. C. P. Lima Júnior ${ }^{3}$, F. B. Sousa ${ }^{1}$, M. R. L. Mota ${ }^{1}$ \& A. P. N. N. Alves ${ }^{1}$

${ }^{1}$ Department of Dental Clinic, Division of Oral Pathology, Faculty of Pharmacy, Dentistry and Nursing, Federal University of Ceara, Fortaleza, Ceara; ${ }^{2}$ Department of Biotechnology, Faculty of Biotechnology, Federal University of Ceara, Fortaleza, Ceara; and ${ }^{3}$ Department of Physiology and Pharmacology, Faculty of Medicine, Federal University of Ceara, Fortaleza, Ceara, Brazil

\begin{abstract}
de Barros Silva PG, Verde MEQL, Brizeno LAC, Wong DVT, Lima Júnior RCP, Sousa FB, Mota MRL, Alves APNN. Immune cell profile of dental pulp tissue treated with zoledronic acid. International Endodontic Journal.
\end{abstract}

Aim To characterize the pulp immune cell profile in the teeth of rats treated with zoledronic acid (ZA).

Methodology Male Wistar rats ( $n=6$ per group) received four intravenous infusions of ZA at doses of $0.04,0.20$ or $1.00 \mathrm{mg} \mathrm{kg}^{-1} \mathrm{ZA}$ or saline (control). On the 70th experimental day, they were euthanized. The first right molar was examined microscopically and submitted to toluidine blue reaction and immunohistochemical for CD68, tumour necrosis Factor (TNF)- $\alpha$, interleukin (IL)- $1 \beta$, inducible nitric oxide synthase (iNOS), nuclear factor kappa B (NF-kB) and IL-18 binding protein (IL-18 bp). The presence of ectasic/dilated vessels and inflammatory cells was analysed, and mast cells and mononuclear CD68-positive cells were counted along with the intensity of immunostaining (0-3) for inflammatory markers in odontoblasts and nonodontoblasts pulp cells. The Kruskal-Wallis/Dunn's test (scores or quantitative data) and the chi-squared test (categorical data) were used (GraphPad Prism 5.0, $P<0.05$ ).

Results There was no differences in the number of animals exhibiting dilated/ectasic blood vessels $(P=0.242)$ and inflammatory cells $(P=0.489)$ or in the number of mast cells $(P=1.000)$. However, there was an increase in mononuclear CD68-positive cells $(P=0.026)$, immunostaining of TNF- $\alpha(P=0.020)$, IL-1 $\beta(P=0.027)$ and iNOS $(P=0.001)$ in odontoblasts, and IL-1 $\beta(P=0.013)$ in nonodontoblast pulp cells dose-dependently. NFkB (nucleus and cytoplasm) and IL-18 bp did not differ between groups.

Conclusion ZA modified the immune cell profile in the dental pulp, increasing the number of macrophages and expression of pro-inflammatory markers independent of NFkB.

Keywords: acute-phase reaction, dental pulp, inflammation, zoledronic acid.

Received 14 March 2016; accepted 7 December 2016

\section{Introduction}

Zoledronic acid (ZA) is a third-generation aminobisphosphonate. It is an analogue of endogenous pyrophosphate and has an antiresorptive power more than 1000 times greater than that of etidronate, the first bisphosphonate used (Oizumi et al. 2009). Due to its potency, high-dose ZA is used for the treatment of diseases such as metastatic cancers of the bone (Silverman \& Landesberg 2009). However, this drug has 
considerable toxicity and is associated with bisphosphonate-related osteonecrosis of the jaws (BRONJ).

ZA is directly toxic to several groups of cells, such as epithelial cells, fibroblasts (Scheper et al. 2009), osteoblasts (Naidu et al. 2008), macrophages (Scheller et al. 2011), neutrophils (Kuiper et al. 2012) and endothelial cells (Misso et al. 2012), and also impairs the maturation of myeloid cells (Wolf et al. 2006). Nevertheless, little is known about its effect on dental pulp cells.

ZA, like sodium alendronate (Hiraga et al. 2010), can lead to dental teratogenicity, and it alters molar eruption and tooth matrix formation, stimulates odontoclastic resorption and induces denticle and odontoma formation (Massa et al. 2006). At low concentrations, ZA increases collagen type I expression. At high concentrations, it affects phosphatase alkaline synthesis and alters the cellular morphology of odontoblasts (Basso et al. 2013). ZA also time-dependently reduces cellular viability, proliferation and protein synthesis in pulp cells (Cvikl et al. 2011).

Tooth physiology involves several events that depend on complex interactions between inflammatory cytokine and protein levels (Rakian et al. 2013). In classical experimental models, amino bisphosphonates increase levels of TNF- $\alpha$ and IL-1 $\beta$ (Norton et al. 2012), which are important cytokines of the pathogenesis of pulpitis (ElSalhy et al. 2013).

Pulpitis is greatly influenced by variations in cytokine levels. Increases in proinflammatory cytokines (Pezelj-ribaric et al. 2002) are related to the development of pulpitis and necrosis (Huang et al. 1999, ElSalhy et al. 2013). This is particularly important when there is a systemic proinflammatory stimulus, such as pharmacological treatments or dental caries (Zadik et al. 2010).

Odontoblasts and nonodontoblast cells can respond to caries (Horst et al. 2011) by increasing the production of IL-8, TNF (Veerayutthwilai et al. 2007) and matrix metalloproteinase (MMP; Accorsi-Mendonça et al. 2013). When this process is added to ZA infusion (Cvikl et al. 2011), there may be further increases in cytokine production, culminating in pulpitis.

Caution is suggested during the endodontic treatment of patients prescribed bisphosphonates due to the risk of BRONJ (Moinzadeh et al. 2013). Endodontic treatment elevates the risk of BRONJ 5.5-fold (Barasch et al. 2011), and there are some case reports of BRONJ induced by pulp and periapical diseases (Katz 2005, Wigler et al. 2013). The major risk factor for
BRONJ is tooth extraction, but ZA infusion generates a paradox: ZA can elevate the risk of developing pulpitis, which requires endodontic treatment, which is a conservative approach in the prevention of BRONJ. However, endodontic treatment also increases the risk of BRONJ. There are no studies characterizing the immune cell profile in the dental pulp of rats treated with bisphosphonates.

In the light of the role of ZA-dependent cytokine overproduction and ZA's ability to modulate the immune response in vivo, the objective of this study was to characterize the pulp immune cell profile in the teeth of rats treated with ZA, through a histological and immunohistochemical study.

\section{Materials and methods}

\section{Sample size calculation}

Using the research by Cvikl et al. (2011) that showed a reduction in the rate of protein synthesis in dental pulp-derived cells treated with ZA $30 \mu \mathrm{mol} \mathrm{mL} \mathrm{mL}^{-1}$ by $24 \mathrm{~h}(75.2 \pm 7.1 \%)$ or $48 \mathrm{~h} \quad(44.1 \pm 19.3 \%)$, a power of $90 \%$ and a confidence of $95 \%$ were adopted to define a sample of five animals ( $t$-test). This calculation was based in the hypothesis that ZA chronic infusion modifies the biology of the dental pulp. Due to the possibility of sample loss during the study, a $20 \%$ increase in the number of animals was planned. So six animals in each group were used $(n=6 /$ group).

\section{Animals, doses and experimental protocols}

Rats ( $n=6 /$ group) received three consecutive weekly intravascular (penile access) infusions of saline or $0.04,0.20$ or $1.00 \mathrm{mg} \mathrm{kg}^{-1}$ of ZA. These doses were calculated by software Dose Calculator provided free by the Food and Drug Administration (http:// www.accessdata.fda.gov). Body weight and surface area were the parameters used for pharmacological conversion of the human dose of ZA for the animals. The mensal dose $(4 \mathrm{mg})$ used to treat multiple myeloma was calculated to be $0.60 \mathrm{mg} \mathrm{kg}^{-1}$ for the Wistar rats and divided into three weekly administrations of $0.20 \mathrm{mg} \mathrm{kg}^{-1}$. Then, a dose-response curve was calculated with three values: $0.20 \mathrm{mg} \mathrm{kg}^{-1}$, five times greater $\left(1.00 \mathrm{mg} \mathrm{kg}^{-1}\right)$ and five times less (0.04 $\mathrm{mg} \mathrm{kg}^{-1}$; Silva et al. 2015).

The infusion was performed on days 00, 07 and 14; on day 49, an additional dose was given; and 
3 weeks later (day 70), the animals were sacrificed, and the hemi-mandibles were fixed in 10\% neutral buffered formalin (Ethics Protocol: 26/13).

After fixation $(24 \mathrm{~h})$, the hemi-mandibles were decalcified (ethylenediaminetetraacetic acid 10\%, pH 7.3) for 30 days to prepare the tissue for microscopic slides.

\section{Histological and histochemical assays}

Microscopic slides $(4 \mu \mathrm{m})$ were deparaffinized, dehydrated and cored by the conventional haematoxylin and eosin (H\&E) method for histological analysis. Hydrated tissue sections $(4 \mu \mathrm{m})$ were immersed in a $0.1 \%$ toluidine blue solution (in $0.9 \%$ sodium chloride) for $60 \mathrm{~s}$ for histochemical assays.

\section{Immunohistochemical assay}

After deparaffinization and rehydration, tissue sections $(2.5 \mu \mathrm{m})$ were used in immunohistochemical assays. Antigenic recuperation was performed by heat in citrate solution ( $\mathrm{pH}$ 6.0). After reaching room temperature, the slides were blocked in peroxidase with 3\% $\mathrm{H}_{2} \mathrm{O}_{2}$ and diluted in PBS (phosphate-buffered saline) or methanol solution (only for NF-kB) for $30 \mathrm{~min}$.

After blocking with albumin for $1 \mathrm{~h}$, the slides were incubated with the following primary antibodies: CD68 (Dako®, Dopenhage, Denmark; 1:500 overnight), Tumor Necrosis Factor (TNF)- $\alpha$ (Abcam ${ }^{\circledR}$, Cambridge, UK; $1: 50$ for $1 \mathrm{~h}$ ), Interleukin (IL)-1 $\beta$ $\left(\right.$ Abcam ${ }^{\circledR}, 1: 100$ for $\left.1 \mathrm{~h}\right)$, Inducible Nitric Oxide Synthase (iNOS; Abcam ${ }^{\circledR}, \quad 1: 200$ overnight), Nuclear Factor kappa B (NF-kB; Santa Cruz ${ }^{\circledR}$, Finnell Street Dallas, TX, USA; 1 : 200 overnight) and IL-18 binding protein (IL-18 bp; Santa Cruz ${ }^{\circledR}, 1: 100$ overnight).

Universal Immune-peroxidase Polymer (Histofine®; [Nicherei Biosciences Inc., Tokyo, Japan] for Dako® or Abcam ${ }^{\circledR}$ primary antibodies; $30 \mathrm{~min}$ ) or secondary biotinylated anti-rabbit IgG (for primary antibodies Santa Cruz®; $30 \mathrm{~min}$ ) plus $\mathrm{ABC}$ System (Santa Cruz ${ }^{\circledR}$; $30 \mathrm{~min}$ ) was used. 5,5-diaminobenzidine tetra hydrochloride (DAB) was used to identify positive cells (Dako®).

\section{Histological, histochemical and immunohistochemical analysis}

The right mandibular first molar of each rat was analysed by optic microscopy at $400 \times$ magnification (five microscopic fields per tooth). To characterize the cell profile of the pulp by H\&E, the presence of ectasic/dilated vessels and inflammatory cells was evaluated. The total CD68-positive mononuclear cells (IHC) and mast cells in this tooth were also counted.

To characterize the inflammatory profile of the pulp, the right mandibular first molar was evaluated, and the percentage of odontoblast and nonodontoblast cells (mesenchymal cells, such as fibroblasts and inflammatory cells) with cytoplasmic (and nuclear for NF-kB) expression of each antibody was characterized as (0) no positive cells; ( 1 - mild) $1-33 \%$ of positive cells; ( 2 - moderate) $34-66 \%$ of positive cells; and (3 - intense) $67-100 \%$ positive cells. The final score was that agreed upon by two observers (kappa $=0.921$; Etemad-Moghadam et al. 2009).

\section{Statistical analysis}

Kruskal-Wallis and Dunn's post-tests were used for scores (Median (Minimum-Maximum)) or mean (mean \pm standard mean error) analysis; the chisquared test (absolute and percentage frequency of the animals) was used for categorical analysis in GraphPad Prism 5.0 software (GraphPad Software, Inc., La Jolla, CA, USA; $P<0.05)$.

\section{Power size calculation}

Based on the mean number of mononuclear CD68+ positive cells that were found in the dental pulp of the $1.00 \mathrm{mg} \mathrm{kg}^{-1}$ ZA-treated group $(2.3 \pm 1.7)$ in relation to the saline group $(0.0 \pm 0.0)$ and considering the sample of six animals per group $(n=6)$, a power of $91.2 \%$ to reject the null hypothesis of this study was calculated (t-test).

\section{Results}

\section{Effect of ZA in the dental pulp}

In the pulp of animals treated with saline or ZA $\left(0.04,0.20\right.$ or $\left.1.00 \mathrm{mg} \mathrm{kg}^{-1}\right)$, there were no significant differences between the four groups. The number of animals exhibiting dilated and ectasic blood vessels $(P=0.242)$ or inflammatory cells $(P=0.489)$ was similar in all groups (Table 1, Fig. 1).

The group given the highest dose of ZA (1.00 $\left.\mathrm{mg} \mathrm{kg}^{-1} ; 2.3 \pm 1.7\right)$ had significantly more mononuclear CD68-positive cells than the saline group $(0.0 \pm 0.0)(P=0.001)$ although there is no 
Table 1 Histological, histochemical and immunohistochemical profile of molar dental pulp in rats treated with ZA or saline

\begin{tabular}{|c|c|c|c|c|c|}
\hline & \multicolumn{5}{|c|}{$\mathrm{ZA}\left(\mathrm{mg} \mathrm{kg}^{-1}\right)$} \\
\hline & Saline & 0.04 & 0.20 & 1.00 & $P$-Value \\
\hline Ectasic/Dilated blood vessels & $6(100.0 \%)$ & $4(66.7 \%)$ & $5(83.3 \%)$ & $6(100.0 \%)$ & $0.242^{\mathrm{a}}$ \\
\hline Inflammatory cells & $3(50.0 \%)$ & $5(83.3 \%)$ & $2(33.3 \%)$ & $3(50.0 \%)$ & $0.489^{a}$ \\
\hline Mononuclear CD68+ & $0.0 \pm 0.0$ & $0.7 \pm 0.3$ & $0.5 \pm 0.4$ & $2.3 \pm 1.7^{\dagger}$ & $0.026^{b}$ \\
\hline Mast cells & $0.0 \pm 0.0$ & $0.0 \pm 0.0$ & $0.0 \pm 0.0$ & $0.0 \pm 0.0$ & $1.000^{\mathrm{b}}$ \\
\hline \multicolumn{6}{|l|}{ Odontoblasts } \\
\hline TNF- $\alpha$ & $0(0-1)$ & $3(2-3)^{\dagger}$ & $3(2-3)^{\dagger}$ & $3(1-3)^{\dagger}$ & $0.020^{\mathrm{b}}$ \\
\hline $\mathrm{IL}-1 \beta$ & $3(2-3)$ & $3(2-3)$ & $3(3-3)^{\dagger}$ & $3(3-3)^{\dagger}$ & $0.027^{b}$ \\
\hline iNOS & $0(0-1)$ & $3(2-3)^{\dagger}$ & $3(3-3)^{\dagger}$ & $3(3-3)^{\dagger}$ & $0.001^{b}$ \\
\hline IL-18 bp & $0(0-0)$ & $0(0-0)$ & $0(0-0)$ & $0(0-1)$ & $0.572^{\mathrm{b}}$ \\
\hline \multicolumn{6}{|l|}{ NF-kB } \\
\hline Nucleus & $0(0-0)$ & $0(0-0)$ & $0(0-0)$ & $0(0-0)$ & $1.000^{\mathrm{b}}$ \\
\hline Cytoplasm & $3(2-3)$ & $3(3-3)$ & $3(3-3)$ & $3(3-3)$ & $0.507^{b}$ \\
\hline \multicolumn{6}{|c|}{ Nonodontoblasts Dental pulp cells } \\
\hline TNF- $\alpha$ & $0(0-2)$ & $1.5(0-3)$ & $1(1-2)$ & $2(1-3)$ & $0.162^{b}$ \\
\hline $\mathrm{IL}-1 \beta$ & $2(1-2)$ & $3(2-3)$ & $3(2-3)$ & $3(3-3)^{\dagger}$ & $0.013^{b}$ \\
\hline iNOS & $0(0-1)$ & $0.5(0-1)$ & $2(1-3)$ & $1(1-2)$ & $0.250^{\mathrm{b}}$ \\
\hline IL-18 bp & $0(0-0)$ & $0(0-0)$ & $0(0-0)$ & $0(0-0)$ & $1.000^{\mathrm{b}}$ \\
\hline \multicolumn{6}{|l|}{ NF-kB } \\
\hline Nucleus & $0(0-0)$ & $0(0-0)$ & $0(0-0)$ & $0(0-0)$ & $1.000^{\mathrm{b}}$ \\
\hline Cytoplasm & $0(0-0)$ & $0(0-0)$ & $0(0-0)$ & $0(0-0)$ & $1.000^{\mathrm{b}}$ \\
\hline
\end{tabular}

${ }^{a}$ Chi-square (data showed as absolute and percentage frequency), $* P<0.05$ versus Saline.

${ }^{\mathrm{b}}$ Kruskal-Wallis/Dunn Test (Median (Minimum-Maximum)). ${ }^{\dagger} P<0.05$ versus Saline.

Scores $=(0)$ no positive cells; $(1-$ mild) $1-33 \%$ of positive cells; $(2-$ moderate) $34-66 \%$ of positive cells; $(3-$ intense) $67-100 \%$ positive cells.

difference in the number of these cells in the groups treated with $0.04 \mathrm{mg} \mathrm{kg}^{-1} \quad(0.7 \pm 0.3)$ or $0.20 \mathrm{mg} \mathrm{kg}^{-1}(0.5 \pm 0.4)$ of $\mathrm{ZA}$ versus saline. No teeth had mast cells in the pulp $(P=1.000$; Table 1 , Fig. 1).

\section{Effect of ZA in odontoblasts}

The groups treated with ZA exhibited high levels of TNF- $\alpha$ expression in the cytoplasm of odontoblasts. The saline group had a median of $0(0-1)$ TNF- $\alpha$-positive cells, but the groups treated with $0.04 \mathrm{mg} \mathrm{kg}^{-1}$ (3, 2-3), $0.20 \mathrm{mg} \mathrm{kg}^{-1}(3,2-3)$ or $1.00 \mathrm{mg} \mathrm{kg}^{-1}$ (3, 1-3) ZA exhibited a median of three TNF- $\alpha$-positive cells, which was significantly higher than the saline group $(P=0.020$; Table 1, Fig. 2$)$.

The number of IL-1 $\beta$-positive odontoblastic cells did not differ between the saline $(3,2-3)$ or $0.04 \mathrm{mg} \mathrm{kg}^{-1} \mathrm{ZA}$ groups (3, 2-3). However, the number of IL-1 $\beta$-positive odontoblasts was significantly higher in the $0.20 \mathrm{mg} \mathrm{kg}^{-1}(3,3-3)$ and $1.00 \mathrm{mg} \mathrm{kg}^{-1}$ (3, 3-3) ZA groups compared with the saline group ( $P=0.027$; Table 1 , Fig. 2$)$.

iNOS immunoexpression was increased in all groups treated with ZA. The number of iNOS-positive odontoblasts in the saline group $(0,0-1)$ was significantly lower than in the $0.04 \mathrm{mg} \mathrm{kg}^{-1}(3,2-3)$, $0.20 \mathrm{mg} \mathrm{kg}^{-1}$ (3, 3-3) and $1.00 \mathrm{mg} \mathrm{kg}^{-1}(3,3-3)$ ZA-treated groups ( $P=0.001$; Table 1 , Fig. 2$)$.

Odontoblasts showed no immunostaining for IL$18 \mathrm{bp}(P=0.572)$ or nuclear immunostaining for NF-kB $(P=1.000)$. However, the odontoblasts in all groups had $100 \%$ cytoplasmic immunostaining for NF-kB ( $P=0.507$; Table 1, Fig. 2).

\section{Chronic treatment with ZA increases IL-1 $\beta$ in nonodontoblast pulp cells}

In nonodontoblast pulp cells, the levels of immunostaining for TNF- $\alpha$ were equal for groups treated with

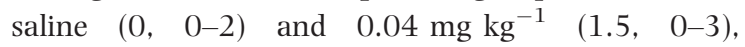
$0.20 \mathrm{mg} \mathrm{kg}^{-1}(1,1-2)$ and $1.00 \mathrm{mg} \mathrm{kg}^{-1} \mathrm{ZA}(2,1-$ 3; $P=0.162$; Table 1, Fig. 2).

The IL-1 $\beta$-positive nonodontoblast cells did not differ between the saline group (1, 1-2), $0.04 \mathrm{mg} . \mathrm{kg}^{-1}$ ZA-treated group (3, 2-3) or $0.20 \mathrm{mg} \cdot \mathrm{kg}^{-1}(3,2-3)$ ZA-treated group. However, the median number of these cells was significantly higher in the $1.00 \mathrm{mg} \mathrm{kg}^{-1}(3,3-3)$ group $(P=0.013$; Table 1 , Fig. 2). 


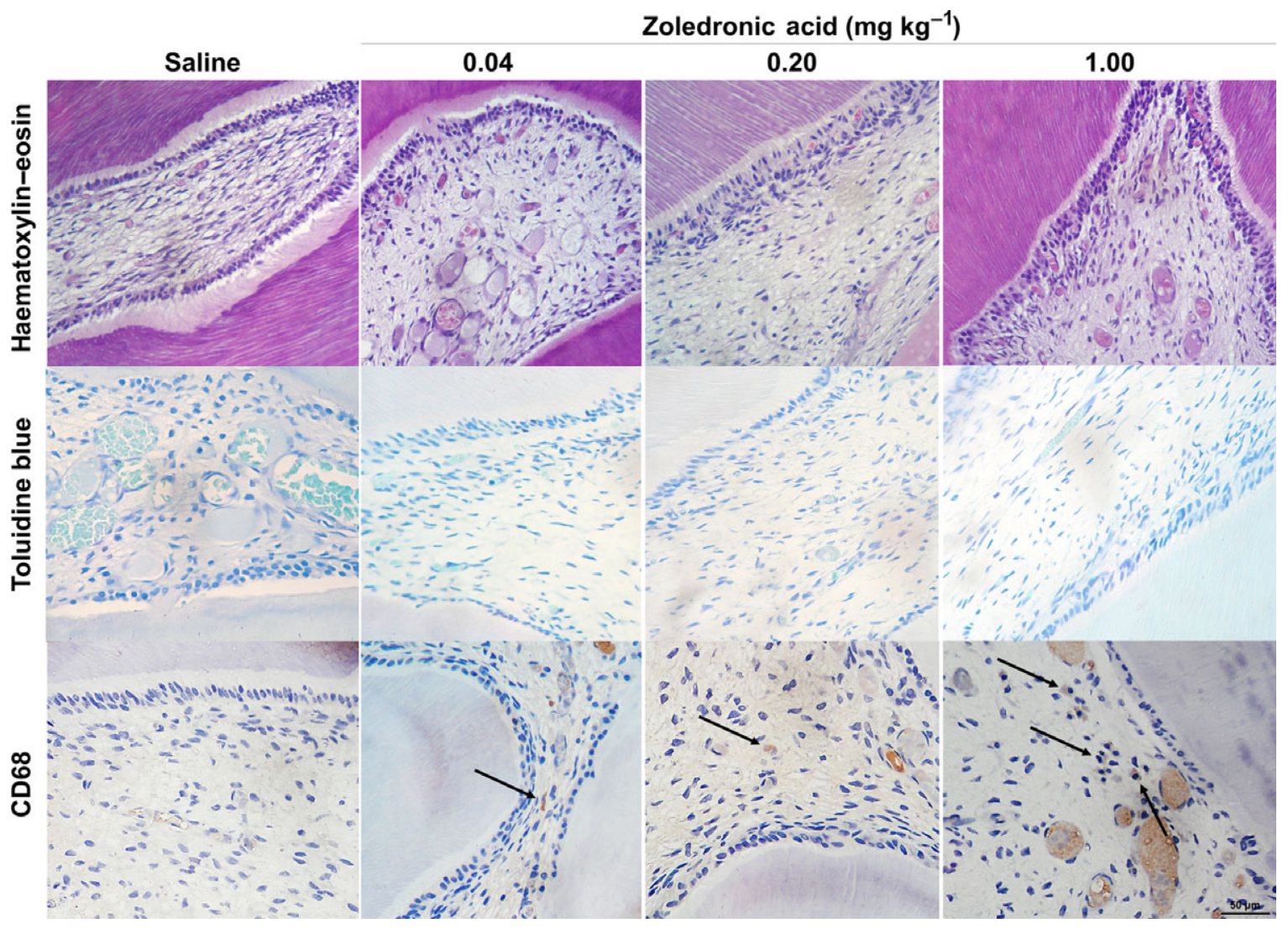

Figure 1 Cellular profile of dental pulp of rats chronically treated with different doses of ZA shows no modification in histological profile or the number of mast cells but an increase in the number of mononuclear CD68-positive cells in the group treated with $1.00 \mathrm{mg} \mathrm{kg}^{-1} \mathrm{ZA}$ compared with the group treated with saline (400x).

There was no difference in iNOS in nonodontoblast pulp cells in the four groups $(P=0.250)$, and none of these cells was positive for IL-18 bp $(P=1.000)$ or NF-kB (nucleus, $P=1.000$; cytoplasm, $P=1.000$; Table 1, Fig. 2).

\section{Discussion}

$\mathrm{ZA}$ is a toxic drug that is used at high doses for the treatment of bone metastases. ZA can deregulate the immune system and increase the number of inflammatory cells and levels of cytokines (Rossini et al. 2012a,b, Norton et al. 2012, Welton et al. 2013).

Mast cells are poorly visualized in the dental pulp by histochemical methods, and their presence is therefore uncertain. The role of mast cells in pulp diseases is unclear (Bruno et al. 2010), but macrophages and dendritic cells, which are mononuclear and CD68 positive, are common cells that appear in the development and normal physiology of the pulp (Iwasaki et al. 2011). In this study, there were a significant number of macrophages in the pulp of rats treated with the highest dose of ZA $\left(1.00 \mathrm{mg} \mathrm{kg}^{-1}\right)$. Macrophages have scavenger receptors (Harre et al. 2012) that recognize apoptotic cells, and they have an important role in defence against caries: macrophages accumulate in the pulp adjacent to cariesaffected regions (Kamal et al. 1997) and phagocyte apoptotic cells (Nishikawa \& Sasaki 1999). These cells can serve as antigen-presenting cells (APC) and migrate to the apical region of teeth (Rungvechvuttivittaya et al. 1998), where they accumulate in response to local overexpression of MCP-1/CCR6 and generate apical granulomas (Liu et al. 2014).

An increase in TNF- $\alpha$ and IL-1 $\beta$ levels was observed. These cytokines are important constitutively expressed markers in the pulp, and they can 


\section{Zoledronic acid $\left(\mathrm{mg} \mathrm{kg}^{-1}\right)$}

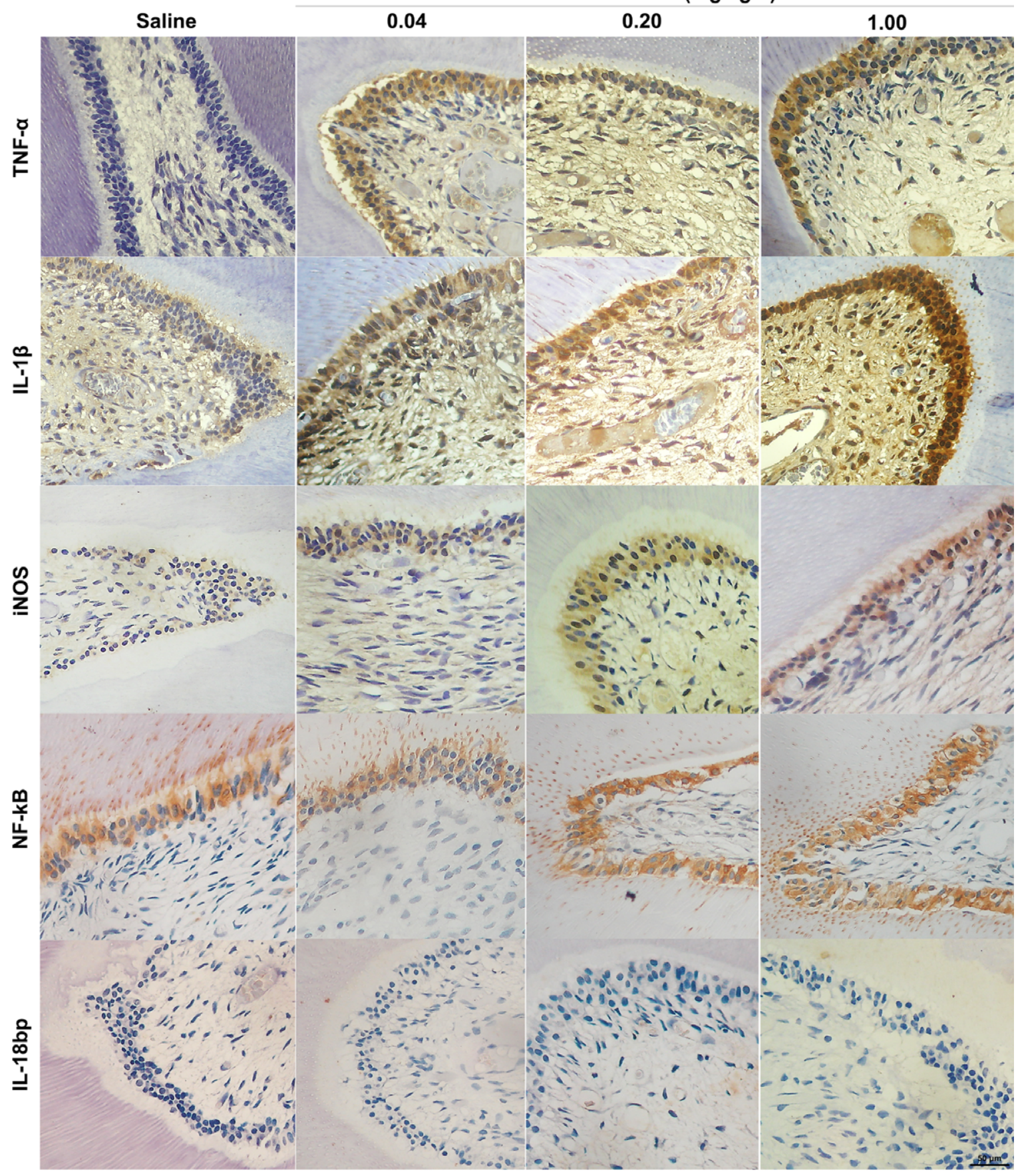

Figure 2 Cytokine profile shows an increase in the number of TNF- $\alpha-$, IL-1 $1 \beta$ - and iNOS-positive immunostained odontoblasts and nonodontoblast dental cells in ZA-treated groups, no changes in constitutive cytoplasmic NF-kB expression in odontoblasts and an absence of IL-18 bp in all groups $(400 \times)$.

activate the death domains in pulp cells, stimulating macrophage infiltration and activation (Ohazama et al. 2003, Paula-Silva et al. 2009). Therefore, these cytokines may play a role in the increased macrophage number in one of the ZA-treated groups. 
There was no significant difference in iNOS expression in nonodontoblast pulp cells between treatment groups, but the odontoblasts of ZA-treated rats were associated with iNOS overexpression. iNOS is only present in inflamed pulps and not in healthy pulps (Di Nardo Di Maio et al. 2004). Odontoblasts are important cells that activate this enzyme in response to caries (Veerayutthwilai et al. 2007, Farges et al. 2015). The iNOS staining may reflect hyperaemia or a state of pulpitis (Di Nardo Di Maio et al. 2004, Veerayutthwilai et al. 2007, Farges et al. 2015). TNF- $\alpha$ and IL-1 $\beta$ (increased in this study) may be partially responsible for the modulation of iNOS activity (Bakker et al. 2009).

ZA did not cause direct toxicity to dental pulp cells. High concentrations of this drug are needed to cause this effect, but tissue damage increases with time (Cvikl et al. 2011).

In the present in vivo study, the ZA dose was converted from human dose to rats. Cvikl et al. (2011) used in vitro empirical doses of 30 or $100 \mu \mathrm{mol} \mathrm{mL}-1$ to identify the toxic dose-dependent effect of ZA in dental pulp cells. So, the comparison of these two protocols is not possible due to the difficulty in demonstrating the real concentration of ZA in the pulp cells of rat's teeth.

The free (not incorporated) ZA is the most associated with ZA toxicity in dental pulp cells (Cvikl et al. 2011). In bone, the toxicity of bisphosphonates appears, whilst osteoclasts demineralization releases the incorporated drug (Baron et al. 2011). The odontoblastic metalloproteinases in inflammatory conditions can explain partially this mechanism. The process of dentine matrix degradation and liberation of bisphosphonates by metalloproteinases can be similar in bone, although slower (Chaussain et al. 2013).

ZA infusion in peritonitis model leads to IL-1 $\beta$ overproduction (Norton et al. 2012). IL-1 is the most important cytokine described in gingival fluid and saliva of BRONJ (Bagan et al. 2013, Tsao et al. 2013). Furthermore, IL-1 $\beta$ is an important cytokine involved in pulpitis (Veerayutthwilai et al. 2007), and it was altered in this study. IL-1 $\beta$ can strongly active odontoblastic metalloproteinases (Hiyama et al. 2013) and augment bisphosphonate liberation in dental pulps raising IL-1 $\beta$ overexpression (included in nondental pulp cells as shown in this study) perpetuating this process.

Odontoblasts and nonodontoblast pulp cells respond by increasing pro-inflammatory cytokine synthesis, and caries can contribute to the rapid development of pulpitis in patients who use bisphosphonates (Horst et al. 2011).

ZA infusion chronically has been associated with an increase in TNF- $\alpha$ (Cheung et al. 2011), IL-1 $\beta$ (Bonewald 2004, Tan et al. 2008) and high oxidative stress by iNOS activity (Almeida et al. 2010). High levels of these mediators modulate excessive apoptosis and act as a stimulus for the recruitment and activation of macrophages (Kogianni et al. 2008, Muratsu et al. 2013). Thus, ZA may contribute to an increase in these proinflammatory markers.

TNF- $\alpha$ and IL-1 $\beta$ are produced by NF- $\kappa \mathrm{B}$ activation, but there was no difference in $\mathrm{NF}-\kappa \mathrm{B}$ levels. $\mathrm{NF}-\kappa \mathrm{B}$ is constitutively expressed in odontoblasts and is important for the production of collagen type I and dentine sialoproteins. Carious stimuli can modulate the immune response in odontoblasts, leading to overexpression of TNF- $\alpha, \quad$ IL-1 $\beta$ and CCL20 (binder of CCR6; Veerayutthwilai et al. 2007), which participate in macrophage infiltration (Liu et al. 2014).

$\mathrm{NF}-\kappa \mathrm{B}$ activation is the primary driver of increased TNF- $\alpha$, IL-1 $\beta$ and iNOS activity, but treatment with ZA did not alter NF- $\mathrm{BB}$ immunostaining. However, physiological expression of $\mathrm{NF}-\kappa \mathrm{B}$ in odontoblasts, accompanied by TNF- $\alpha$ and IL-1 $\beta$ overexpression, leads to pulp cell death (Hozhabri et al. 2015). In the pulp, there are complex ways to regulate these interactions, and other proteins can be involved in this process (ABCF1, FOS, IRF3, SP1, STA3, STAT1, FOXO, ERK1, TNFR and many others; Horst et al. 2011). Cytokine production in dental pulp tissue is increased in the presence of lipopolysaccharide (LPS), but a reduction in I $\mathrm{\kappa B}-\alpha$ activity, even in the presence of LPS, leads to an increase in TNF- $\alpha$, IL- $1 \beta$ and IL-6 (Muratsu et al. 2013); thus, other mechanisms are responsible for this alteration in the dental pulp of rats treated with ZA.

ZA increased the expression of proinflammatory cytokines, independent from LPS. The addition of caries may further increase the production of these mediators, modifying the immune profile in the pulp and leading rapidly to an inflammatory disease with pulp damage and irreversible pulpitis and necrosis (ElSalhy et al. 2013).

Chemotherapies that alter the immune system can lead to odontalgia (Zadik et al. 2010), and it has been shown that high doses of ZA used chronically in chemotherapy protocols can modulate the immune response in dental pulps. 


\section{Conclusion}

ZA modified the immune cell profile in the dental pulp, increasing the number of macrophages and expression of pro-inflammatory markers (TNF- $\alpha$, IL-1 $\beta$ and iNOS) independently of NF-kB immunostaining. This is the first study in vivo showing this relationship. However, more studies are needed to investigate the ways that ZA can increase cytokine expression in the dental pulp.

\section{Acknowledgements}

This study was partially designed by and is dedicated to Professor Ronaldo Albuquerque Ribeiro (Laboratório de Farmacologia da Inflamação e do Câncer), who is no longer amongst us.

\section{Conflict of Interest}

The authors have stated explicitly that there are no conflict of interests in connection with this article.

\section{References}

Accorsi-Mendonça T, Silva EJ, Marcaccini AM et al. (2013) Evaluation of gelatinases, tissue inhibitor of matrix metalloproteinase-2, and myeloperoxidase protein in healthy and inflamed human dental pulp tissue. Journal of Endodontics 39, 879-82.

Almeida M, Li H, Ambrogini E, Shoshana MB, Manolagas SC (2010) Oxidative stress stimulates apoptosis and activates NF-kappaB in osteoblastic cells via a PKCbeta/p66shc signaling cascade: counter regulation by estrogens or androgens. Molecular Endocrinology 24, 2030-7.

Bagan J, Sheth CC, Soria JM et al. (2013) Bisphosphonatesrelated osteonecrosis of the jaws: a preliminary study of salivary interleukins. Journal of Oral Pathology and Medicine 42, 405-8.

Bakker AD, Silva VC, Krishnan R et al. (2009) Tumor necrosis factor alpha and interleukin-1beta modulate calcium and nitric oxide signaling in mechanically stimulated osteocytes. Arthritis Rheumatism 60, 3336-45.

Barasch A, Cunha-Cruz J, Curro FA et al. (2011) Risk factors for osteonecrosis of the jaws: a case-control study from the CONDOR dental PBRN. Journal of Dental Research 90, 439-44.

Baron R, Ferrari S, Russell RG (2011) Denosumab and bisphosphonates: different mechanisms of action and effects. Bone 48, 677-92.

Basso FG, Turrioni PS, Hebling J, de Souza Costa CA (2013) Effects of zoledronic acid on odontoblast-like cells. Archives of Oral Biology 58, 467-73.
Bonewald LF (2004) Osteocyte biology: its implications for osteoporosis. Journal of Musculoskeletal and Neuronal Interactions 4, 101-4.

Bruno KF, Silva JA, Silva TA, Batista AC, Alencar AHG, Estrela C (2010) Characterization of inflammatory cell infiltrate in human dental pulpitis. International Endodontic Journal 43, 1013-21.

Chaussain C, Boukpessi T, Khaddam M, Tjaderhane L, George A, Menashi S (2013) Dentin matrix degradation by host matrix metalloproteinases: inhibition and clinical perspectives toward regeneration. Frontiers in Physiology 4, 1-8.

Cheung WY, Liu C, Tonelli-Zasarsky RM, Simmons CA, You L (2011) Osteocyte apoptosis is mechanically regulated and induces angiogenesis in vitro. Journal of Orthopaedic Research 29, 523-30.

Cvikl B, Agis H, Stögerer K, Moritz A, Watzek G, Gruber R (2011) The response of dental pulp-derived cells to zoledronate depends on the experimental model. International Endodontic Journal 44, 33-40.

Di Nardo Di Maio F, Lohinai Z, Darcangelo C et al. (2004) Nitric oxide synthase in healthy and inflamed human dental pulp. Journal of Dental Research 83, 312-6.

ElSalhy M, Azizieh F, Raghupathy R (2013) Cytokines as diagnostic markers of pulpal inflammation. International Endodontic Journal 46, 573-80.

Etemad-Moghadam S, Khalili M, Tirgary F, Alaeddini M (2009) Evaluation of myofibroblasts in oral epithelial dysplasia and squamous cell carcinoma. Journal of Oral Pathology and Medicine 38, 639-43.

Farges JC, Bellanger A, Ducret M et al. (2015) Human odontoblast-like cells produce nitric oxide with antibacterial activity upon TLR2 activation. Frontiers in Physiology 6 , $1-9$.

Harre U, Keppeler H, Ipseiz N et al. (2012) Moonlighting osteoclasts as undertakers of apoptotic cells. Autoimmunity 45, 612-9.

Hiraga T, Ninomiya T, Hosoya A, Nakamura H (2010) Administration of the Bisphosphonate Zoledronic Acid During Tooth Development Inhibits Tooth Eruption and Formation and Induces Dental Abnormalities in Rats. Calcified Tissue International 86, 502-10.

Hiyama T, Ozeki N, Mogi M et al. (2013) Matrix metalloproteinase-3 in odontoblastic cells derived from ips cells: unique proliferation response as odontoblastic cells derived from ES cells. PLoS ONE 8, e83563.

Horst OV, Horst JA, Samudrala R, Dale BA (2011) Caries induced cytokine network in the odontoblast layer of human teeth. BMC Immunology 12, 9. doi:10.1186/14712172-12-9.

Hozhabri NST, Benson MD, Vu MD et al. (2015) Decreasing NF- $\mathrm{BB}$ Expression Enhances Odontoblastic Differentiation and Collagen Expression in Dental Pulp Stem Cells Exposed to Inflammatory Cytokines. PLOS ONE 10, e0113334. 
Huang GT, Potente AP, Kim JW, Zhang X (1999) Increased interleukin-8 expression in inflamed human dental pulps. Oral Surgery, Oral Medicine, Oral Pathology, Oral Radiology, and Endodontology 88, 214-20.

Iwasaki Y, Otsuka H, Yanagisawa N et al. (2011) In situ proliferation and differentiation of macrophages in dental pulp. Cell Tissue Research 346, 99-109.

Kamal MMA, Okiji T, Kawashima N, Suda H (1997) Defense responses of dentin/pulp complex to experimentally induced caries in rat molars: an immunohistochemical study on kinetics of pulpal la antigen-expressing cells and macrophages. Journal of Endodontics 23, 115-20.

Katz H (2005) Endodontic implications of bisphosphonateassociated osteonecrosis of the jaws: a report of three cases. Journal of Endodontics 31, 831-4.

Kogianni G, Mann V, Noble BS (2008) Apoptotic bodies convey activity capable of initiating osteoclastogenesis and localized bone destruction. Journal of Bone and Mineral Research 23, 915-27.

Kuiper JWP, Forster C, Sun C, Peel S, Glogauer M (2012) Zoledronate and pamidronate depress neutrophil functions and survival in mice. British Journal of Pharmacology 16, 532-9.

Liu L, Wang L, Wu Y, Peng B (2014) The expression of MCP-1 and CCR2 in induced rats periapical lesions. Archives of Oral Biology 59, 492-9.

Massa LF, Bradaschia-Correa V, Arana-Chavez VE (2006) Immunocytochemical study of amelogenin deposition during the early odontogenesis of molars in alendronate-treated newborn rats. Journal of Histochemistry and Cytochemistry 54, 713-25.

Misso G, Porru M, Stoppacciaro A et al. (2012) Evaluation of the in vitro and in vivo antiangiogenic effects of denosumab and zoledronic acid. Cancer Biology and Therapy 13, 1491-500.

Moinzadeh AT, Shemesh H, Neirynck NA, Aubert C, Wesselink PR (2013) Bisphosphonates and their clinical implications in endodontic therapy. International Endodontic Journal 46, 391-8.

Muratsu D, Yoshiga D, Taketomi T et al. (2013) Zoledronic acid enhances lipopolysaccharide-stimulated proinflammatory reactions through controlled expression of SOCS1 in macrophages. PLoS ONE 8, e67906.

Naidu A, Dechow PC, Spears R, Wright JM, Kessler HP, Opperman L (2008) The effects of bisphosphonates on osteoblasts in vitro. Oral Surgery, Oral Medicine, Oral Pathology, Oral Radiology, and Endodontology 106, $5-13$.

Nishikawa S, Sasaki F (1999) Apoptosis of dental pulp cells and their elimination by macrophages and MHC class IIexpressing dendritic cells. Journal of Histochemistry and Cytochemistry 47, 303-11.

Norton JT, Hayashi T, Brian C et al. (2012) Cutting Edge: nitrogen bisphosphonate-induced inflammation is dependent upon mast cells and IL-1. Journal of Immunology 188, 2977-80.

Ohazama A, Courtney JM, Sharpe PT (2003) Expression of TNF-receptor-associated factor genes in murine tooth development. Gene Expression Patterns 3, 127-9.

Oizumi T, Yamaguchi K, Funayama H et al. (2009) Necrotic actions of nitrogen-containing bisphosphonates and their inhibition by clodronate, a non-nitrogen-containing bisphosphonate in mice: potential for utilization of clodronate as a combination drug with a nitrogen-containing bisphosphonate. Basic and Clinical Pharmacology and Toxicology 104, 384-92.

Paula-Silva FWG, Ghosh A, La Silva B, Kapila YL (2009) TNF-alpha promotes an odontoblastic phenotype in dental pulp cells. Journal of Dental Research 88, 339-44.

Pezelj-ribaric S, Anic I, Brekalo I, Miletic I, Simunovic-Soskic M (2002) Detection of tumor necrosis factor $\alpha$ in normal and inflamed human dental pulps. Archives of Medical Research 33, 482-4.

Rakian A, Yang WC, Gluhak-Heinrich J et al. (2013) Bone morphogenetic protein-2 gene controls tooth root development in coordination with formation of the periodontium. International Journal of Oral Sciences 5, 7584.

Rossini M, Adami S, Viapiana O et al. (2012a) Long-term effects of amino-bisphosphonates on circulating $\gamma \delta \mathrm{T}$ cells. Calcified Tissue International 91, 395-9.

Rossini M, Adami S, Viapiana O et al. (2012b) Circulating $\gamma \delta \mathrm{T}$ cells and the risk of acute-phase response after zoledronic acid administration. Journal of Bone and Mineral Research 27, 227-30.

Rungvechvuttivittaya S, Okiji T, Suda H (1998) Responses of macrophage-associated antigen-expressing cells in the dental pulp of rat molars to experimental tooth replantation. Archives of Oral Biology 43, 701-10.

Scheller EL, Hankenson KD, Reuben JS, Krebsbach PH (2011) Zoledronic acid inhibits macrophage SOCS3 expression and enhances cytokine production. Journal of Cellular Biochemistry 112, 3364-72.

Scheper M, Badros A, Chaisuparat R, Cullen KJ, Meiller TF (2009) Effect of zoledronic acid on oral fibroblasts and epithelial cells: a potential mechanism of bisphosphonateassociated osteonecrosis. British Journal of Haematology 144, 667-76.

Silva PGB, Ferreira Junior AEC, Teófilo CR et al. (2015) Effect of different doses of zoledronic acid in establishing of bisphosphonate-related osteonecrosis. Archives of Oral Biology 60, 1237-45.

Silverman SL, Landesberg R (2009) Osteonecrosis of the jaw and the role of bisphosphonates: a critical review. The American Journal of Medicine 122, S33-45.

Tan SD, Bakker AD, Semeins CM, Kuijpers-Jagtman AM, Klein-Nulend J (2008) Inhibition of osteocyte apoptosis by fluid flow is mediated by nitric oxide. Biochemical and Biophysical Research Communications 369, 1150-4. 
Tsao C, Darby I, Ebeling PR et al. (2013) Oral health risk factors for bisphosphonate-associated jaw osteonecrosis. Journal of Oral and Maxillofacial Surgery 71, 1360-6.

Veerayutthwilai O, Byers MR, Pham TT, Darveau RP, Dale BA (2007) Differential regulation of immune responses by odontoblasts. Oral Microbiology and Immunology 22 , 5-13.

Welton JL, Morgan MP, Martí S et al. (2013) Monocytes and $\gamma \delta \mathrm{T}$ cells control the acute-phase response to intravenous zoledronate: insights from a phase IV safety trial. Journal of Bone and Mineral Research 28, 464-71.
Wigler R, Steinbock N, Berg T (2013) Oral cutaneous sinus tract, vertical root fracture, and bisphosphonate-related osteonecrosis: a case report. Journal of Endodontics 39 , 1088-90.

Wolf AM, Tilg H, Gunsilius E (2006) The effect of zoledronic acid on the function and differentiation of myeloid cells. Haematologica 91, 1165-71.

Zadik Y, Vainstein V, Heling I, Neuman T, Drucker S, Elad S (2010) Cytotoxic chemotherapy-induced odontalgia: a differential diagnosis for dental pain. Journal of Endodontics 36, 1588-92. 